\title{
Relationship between serum insulin-like growth factor-1, IGF binding protein-3 levels and body height before and after gonadotropin-releasing hormone agonist therapy
}

\author{
Han Sol Song, MD, \\ Won Bok Choi, MD, \\ Joon Sup Song, MD, \\ II Tae Hwang, MD, \\ Seung Yang, MD
}

\section{Department of Pediatrics, Hallym} University College of Medicine, Seoul, Korea
Received: 12 September, 2014 Revised: 6 October, 2014 Accepted: 16 December, 2014

Address for correspondence: Seung Yang, MD

Department of Pediatrics, Hallym University Kangdong Sacred Heart Hospital, 150 Seongan-ro, Gangdong-gu, Seoul 134-701, Korea

Tel: +82-2-2224-2251

Fax: +82-2-482-8334

E-mail: drsyang@hallym.or.kr
Purpose: The gonadotropin-releasing hormone agonist ( $\mathrm{GnRHa}$ ) is widely used to treat patients with precocious puberty. However, its effect on growth is often difficult to predict because of the diverse nature of its causes and presentation. This study aims to show the impact of GnRHa treatment on insulin-like growth factor-1 (IGF-I) and IGF binding protein-3 (IGFBP-3) secretion, growth, and on other parameters that may help estimate the height velocity.

Methods: Data from 60 girls (mean age, $8.8 \pm 0.7$ years) treated with GnRHa were analyzed. Their height, bone age (BA), serum IGF-I, and IGFBP-3 concentrations were measured at the start and after a year of GnRHa treatment. To eliminate the confounding effect of chronological age (CA), the standard deviation scores (SDSs) of their height, IGF-I, and IGFBP-3 concentrations according to their CA at the start and after a year of GnRHa treatment were calculated. We looked for possible correlations between these variables and compared the subgroups based on their height velocities and midparental heights.

Results: During their one-year GnRHa therapy, height SDS for CA significantly decreased to $0.81 \pm 0.83(P<0.001)$, but height SDS for BA increased to $-0.28 \pm 0.68$ $(P<0.001)$. There was no significant change in serum IGF-I SDS, IGFBP-3 SDS, and IGF-I/IGFBP-3 ratio. The advanced BA was the factor most strongly correlated to the height velocity $(R=0.265, P=0.041)$.

Conclusion: These findings suggest that GnRHa treatment may affect the height velocity due to mechanisms other than suppression of the IGF-I and IGFBP-3 secretory axis.

Keywords: Precocious puberty, Insulin-like growth factor I, Body height

\section{Introduction}

Precocious puberty is generally defined as the appearance of secondary sex characteristics before the age of 8 years in girls and 9 years in boys ${ }^{11}$. Central precocious puberty (CPP) is a subtype of precocious puberty, which is caused by early maturation of the hypothalamicpituitary-gonadal $\mathrm{axis}^{2}$. Studies have reported a significant increase in the incidence of $\mathrm{CPP}^{3)}$. For example, in 2006-2011, there was a four- to five-fold increase in the number of CPP patients among Korean girls ${ }^{4}$. As such, the physical and psychological effects of CPP on the affected children are becoming increasingly important.

Children with true precocious puberty or early puberty tend to exhibit temporary accelerated growth due to increased sex hormones, but also a shorter growing period, which ultimately lead to a lower final adult height (FAH). Increased sex hormones shortens growing 
period by promoting growth plate senescence, which refers to the structural and functional changes of epiphyseal plate including decline in chondrocyte proliferation and rate of longitudinal bone growth ${ }^{5,6)}$.

Treatment of precocious puberty with the gonadotropinreleasing hormone agonist (GnRHa) was introduced in 1981, and it is now widely used and is known to increase $\mathrm{FAH}^{7,8)}$. GnRHa binds to the gonadotropin-releasing hormone (GnRH) receptors in the gonadotropic cells of the anterior pituitary gland, initially resulting in a brief surge of luteinizing hormone (LH) and follicle-stimulating hormone (FSH). Then it is followed by desensitization of the GnRH receptors and eventual gonadal suppression due to down-regulation of the intrinsic pulsatile secretion of the $\mathrm{LH}$ and $\mathrm{FSH}^{9}$. GnRHa treatment thus suppresses bone maturation, which normalizes the height velocity according to the chronological age (CA).

However some studies have reported a drop in the height velocity to below the normal range, possibly due to suppression of the secretory axis of the insulin-like growth factor I (IGF-I) and the IGF binding protein 3 (IGFBP-3) secondary to the reduced sex hormones ${ }^{10)}$.

The response of precocious puberty patients to GnRHa treatment is often difficult to predict, mainly because of the diverse nature of the clinical presentation of the disease and its underlying causes. Partsch et al. ${ }^{11)}$ suggested that CPP was a continuum of clinical presentations and rates of progression that range from normal variants or incomplete forms of pubertal development to slowly progressive or transient forms and rapidly progressive forms. The factors affected the better response to GnRHa treatment and final height outcome are: a younger $\mathrm{CA}$ at puberty or at the start of treatment, an advanced bone age (BA), a shorter interval between the onset of the CPP and its treatment, a greater height at the initial evaluation, the target height, the predicted adult height before the treatment, and the duration of the treatment ${ }^{12-15}$. Other genetic factors may also affect the efficacy of GnRHa treatment ${ }^{16)}$.

This study aims to show the impact of GnRHa treatment on IGF-I and IGFBP-3 secretion, growth, and on other anthropometric or laboratory parameters that may help estimate the height velocity.

\section{Materials and methods}

\section{Patients}

The subjects were 60 girls who started GnRHa treatment at our center from May 2010 to June 2012, including 10 girls who were diagnosed as having had true precocious puberty. All the subjects experienced breast development above Tanner Stage B2 before 9 years of CA, had recently experienced rapid growth in height or body weight, and more than one year advanced BA. The subjects who were born small for their gestational age, whose magnetic resonance imaging showed an intracranial lesion, who had other endocrine diseases, and who received concurrent growth hormone therapy were excluded. Long-acting GnRHa (triptorelin or leuprorelin $3.75 \mathrm{mg}$ ) was administered as subcutaneous injection every 28 days.

\section{Measurements}

The height, BA, and serum IGF-I, IGFBP-3, LH, FSH and estradiol concentrations of all the patients were measured at the start and after a year of GnRHa treatment. The height was measured to the nearest $0.1 \mathrm{~cm}$ using a Harpenden Stadiometer (Holtain Ltd., Crymych, UK). The heights of both parents of each subject were also recorded on a questionnaire. BA was assessed by comparing the plain left-hand radiographs of patients with reference data set published by Greulich and Pyle ${ }^{177}$.

\section{Statistics}

To eliminate confounding effect of age, age-adjusted height velocity was defined as the difference between standard deviation score (SDS) of height after a year of treatment and that at the diagnosis. SDSs for IGF-I and IGFBP-3 concentrations based on the CA were also calculated. The SDSs were calculated using Cole's modified LMS methods ${ }^{18)}$. For the height, we used the L (box-cox power), M (median), and S (coefficient of variation) values provided by the Growth Charts of Korean Children and Adolescents, which was published by the Korea Centers for Disease Control and Prevention in 2007. For IGF-I and IGFBP-3, we estimated the parameters from the percentile values for the age of Korean girls using the Levenberg-Marquardt algorithm ${ }^{19,20)}$. The IGF-I:IGFBP-3 molar ratios were calculated at the start and after a year of treatment. The respective values at the start and after a year of treatment were compared using a paired $t$-test, and Pearson correlation coefficient was used to measure the correlation between the age-adjusted height velocity and other measured or derived parameters (i.e., the IGF-I SDS, IGFBP-3 SDS, and IGF-I/ IGFBP-3 molar ratio at the start and after a year of treatment, the difference between the two values, and the midparental height). The subjects were divided into subgroups based on the differences in their height SDSs for CA or their mid-parental heights. The same statistical analyses were performed for each subgroup. The statistical analyses were performed using the IBM SPSS Statistics ver. 21.0 (IBM Co., Armonk, NY, USA). Value of $P<0.05$ was considered statistically significant.

\section{Results}

At the start of the GnRHa treatment, the mean chronological and BAs were $8.77 \pm 0.70$ years and $10.38 \pm 0.76$ years, respectively. Serum LH and estradiol concentrations decreased significantly, indicating adequate gonadal suppression $(1.62 \pm 2.07$ to $1.31 \pm 1.82, P<0.001$; and $5.17 \pm 5.06$ to $3.32 \pm 3.11, P=0.024$, respectively). Serum FSH concentrations had no significant difference. 
The height SDS according to the CA was $1.01 \pm 0.84$, and the height SDS according to the BA was $-0.64 \pm 0.88$. The SDSs for the serum IGF-I and IGFBP- 3 concentrations were $0.48 \pm 0.89$ and $2.96 \pm 0.94$, respectively, and the IGF-I/IGFBP- 3 ratio was $59.3 \pm 13.7$. The mean midparental height was $159.6 \pm 3.7 \mathrm{~cm}$. After a year of GnRHa treatment, the BA became $10.89 \pm 0.49$ years. The difference between the BA and the CA significantly decreased from $1.61 \pm 0.82$ to $1.12 \pm 0.72(P<0.001)$, which indicates adequate suppression of the growth plate senescence. The height SDS according to the CA significantly decreased to $0.81 \pm 0.83(P<0.001)$, but the height SDS according to the BA significantly increased to $-0.28 \pm 0.68(P<0.001)$. There was no significant change in the serum IGF-I, IGFBP-3 SDSs, and IGF-I/ IGFBP-3 ratio (Table 1).

Girls whose BA was more advanced than their CA tended to have a greater age-adjusted height velocity for both their CA

Table 1. Characteristics of the 60 girls treated with the GnRH agonist

\begin{tabular}{lcc}
\hline Characteristic & At the diagnosis & After a year \\
\hline CA (yr) & $8.77 \pm 0.70$ & - \\
BA (yr) & $10.38 \pm 0.76$ & $10.89 \pm 0.49$ \\
BA-CA (yr) & $1.61 \pm 0.82$ & $1.12 \pm 0.72^{*}$ \\
Height SDS for the CA & $1.01 \pm 0.84$ & $0.81 \pm 0.83^{*}$ \\
Height SDS for the BA & $-0.64 \pm 0.88$ & $0.28 \pm 0.68^{*}$ \\
IGF-I SDS & $0.48 \pm 0.89$ & $0.40 \pm 0.82$ \\
IGFBP-3 SDS & $2.96 \pm 0.94$ & $3.17 \pm 0.89$ \\
IGF-I/IGFBP-3 & $59.3 \pm 13.7$ & $59.6 \pm 12.7$ \\
Midparental height $(\mathrm{cm})$ & $159.6 \pm 3.7$ & - \\
\hline
\end{tabular}

Values are presented as mean \pm standard deviation.

$\mathrm{GnRH}$, gonadotropin-releasing hormone; CA, chronological age; BA, bone age; SDS, standard deviation score; IGF-I, insulinlike growth factor I; IGFBP-3, insulin-like growth factor binding protein 3.

${ }^{*} P<0.05$ compared to before the treatment.

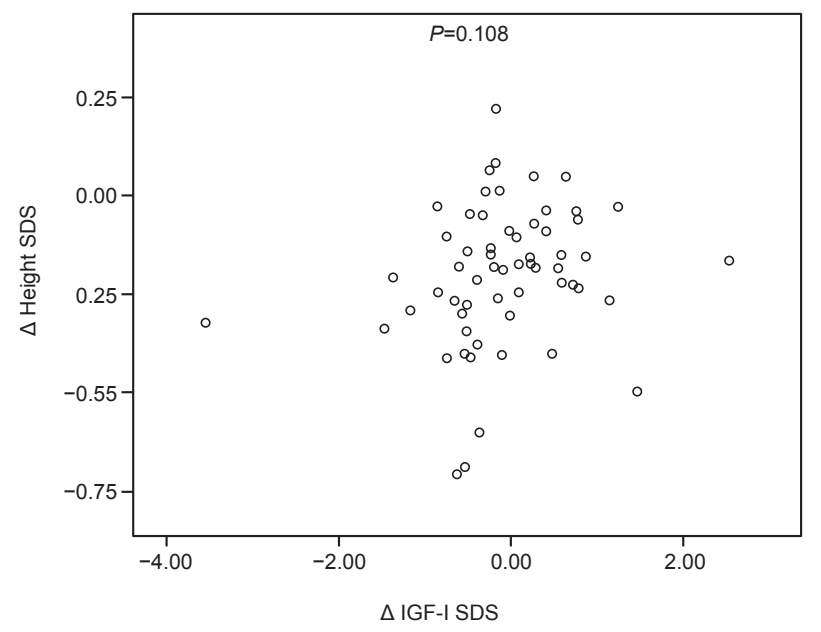

Fig. 1. Scatter plot of the relationship between the changes in the IGF-I SDS and the height SDS during the GnRHa treatment. IGF-I, insulin-like growth factor I: SDS, standard deviation score; GnRHa, gonadotropin-releasing hormone agonist.
$(R=0.265, P=0.041)$ and BA $(R=0.642, P<0.001)$. Girls with a higher $\mathrm{BA}$ at the start of their treatment also had a greater ageadjusted height velocity for their $\mathrm{BA}(R=0.753, P<0.001)$. Ageadjusted height velocity for both $\mathrm{CA}$ and BA did not correlate with IGF-I, IGFBP-3, IGF-I:IGFBP-3 ratio, or sex hormones (Figs. 1 and 2). No other significant correlation between the variables was evident.

The mean age-adjusted height velocity for CA during the treatment was -0.20 , and 33 subjects had a greater difference than the mean (Table 2). Between the two subgroups (that with a below-the-mean difference in their height SDS, and that with an above-the-mean difference in their height SDS), the above-themean group had a higher serum IGF-I concentration SDS for their CA after their treatment $(0.52 \pm 0.96$ vs. $0.25 \pm 0.60, P=0.048)$. The below-the-mean group had a higher IGF-I/IGFBP-3 ratio after their treatment $(60.7 \pm 15.7$ vs. $58.9 \pm 9.6, \mathrm{P}=0.018)$. However, the ratio increased during the treatment in the above-the-mean group, whereas the below-the-mean group showed a decrease (2.0 \pm 9.0 vs. $-1.6 \pm 15.9, P=0.037)$. No significant correlation between the variables was found in each subgroup.

Subgroup analysis was also performed between the belowthe-mean and above-the-mean groups for their midparental heights (below and above: $159.6 \mathrm{~cm} ; \mathrm{n}=32$ and 28, respectively) to elucidate the potential effect of genetic factors on the height velocity. The two subgroups showed no significant difference, and no significant correlation between the variables was evident in each subgroup.

\section{Discussion}

The role of IGF-I as a modulator of maturational timing is being increasingly recognized, and several investigators have examined the effect of gonadal suppression with GnRHa on the growth hormone axis and the height velocity with conflicting

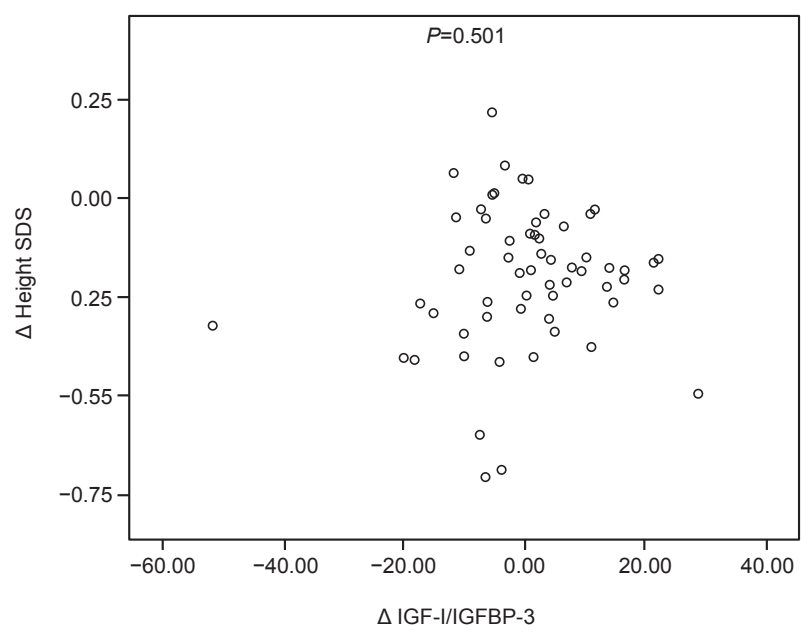

Fig. 2. Scatter plot of the relationship between the changes in the IGF-1:IGFBP-3 ratio and the height SDS during the gonadotropin-releasing hormone agonist treatment. IGF-I, insulin-like growth factor I; IGFBP-3, insulin-like growth factor binding protein 3; SDS, standard deviation score. 


\begin{tabular}{|c|c|c|c|}
\hline Variable & $\begin{array}{l}\text { Group A } \\
(n=33)^{a)}\end{array}$ & $\begin{array}{l}\text { Group B } \\
(n=27)^{b)}\end{array}$ & $P$-value \\
\hline Midparental height (cm) & 160.2 & 158.8 & 0.281 \\
\hline CA before the treatment (yr) & 8.64 & 8.91 & 0.553 \\
\hline \multicolumn{4}{|l|}{ Bone age (yr) } \\
\hline Before & 10.31 & 10.46 & 0.926 \\
\hline After & 10.84 & 10.94 & 0.563 \\
\hline Difference & 0.53 & 0.48 & 0.937 \\
\hline \multicolumn{4}{|l|}{ Height SDS } \\
\hline Before & 0.89 & 1.15 & 0.437 \\
\hline After & 0.81 & 0.80 & 0.347 \\
\hline Difference & -0.08 & -0.35 & 0.189 \\
\hline \multicolumn{4}{|l|}{ IGF-I SDS } \\
\hline Before & 0.37 & 0.61 & 0.633 \\
\hline After ${ }^{*}$ & 0.52 & 0.25 & 0.048 \\
\hline Difference & 0.15 & -0.35 & 0.275 \\
\hline \multicolumn{4}{|l|}{ IGFBP-3 SDS } \\
\hline Before & 2.97 & 2.94 & 0.854 \\
\hline After & 3.09 & 3.28 & 0.165 \\
\hline Difference & 0.13 & 0.34 & 0.112 \\
\hline \multicolumn{4}{|l|}{ IGF-I/IGFBP-3 } \\
\hline Before & 57.3 & 62.3 & 0.189 \\
\hline After $^{*}$ & 58.9 & 60.7 & 0.018 \\
\hline Difference $^{*}$ & 2 & -1.6 & 0.037 \\
\hline
\end{tabular}

SDS, standard deviation score; GnRH, gonadotropin-releasing hormone; CA, chronological age; SDS, standard deviation score; IGF-I, insulin-like growth factor I; IGFBP-3, insulin-like growth factor binding protein $3 ; \triangle$, difference between the value after a year of treatment and that at the diagnosis.

a) $\triangle$ Height SDS $\geq-0.20$. ${ }^{\text {b) }} \Delta$ Height $S D S<-0.20 .{ }^{*} P<0.05$ between the two subgroups.

results. Significant decreases in the serum somatomedin-C concentration and in the mean growth hormone level after treatment with GnRHa have been reported ${ }^{21,22)}$. A previous analysis of the height velocities and the serum IGF-I and IGFBP-3 levels of 26 Korean girls also showed significant decreases in the serum IGF-I and IGFBP-3 concentrations after a year of GnRHa treatment, but unchanged normal height velocities ${ }^{23}$. Other studies have reported no significant change in the IGF-I and IGFBP-3 concentrations despite a decrease in the height velocity ${ }^{24,25)}$.

In this study, there was a significant decrease in the height velocity but not in the mean IGF-I and IGFBP- 3 concentrations. These results imply that gonadal suppression may influence growth via direct pathways independent of the circulating IGF-I. The exact mechanism of the effect of sex steroids on the growth plate still needs investigation. Kanety et al. ${ }^{24)}$ suggested that sex steroids have a role in inducing an increase in the IGF-I and IGFBP-3 axis, but may not be important in the subsequent maintenance of the levels of these hormones. This conclusion may be applicable to other groups of patients, since male patients with virilizing congenital adrenal hyperplasia have shown that hydrocortisone therapy suppresses testosterone without suppressing IGF- ${ }^{24,26)}$.

Lack of change in IGF-I and IGFBP-3 with decrease in sex hormones level and height velocity signifies direct effect of sex hormones on growth. One possible explanation is that the sex hormones directly affect bone growth. In vitro and animal studies have shown that sex steroids may act via the locally produced IGF-I in the target tissues without significantly raising the circulating IGF-I concentrations, with the bone as a target $\operatorname{organ}^{9)}$. The exact quantitative role of growth and the sex hormones on the height velocity needs further investigation.

According to Weise et al. ${ }^{27}$, the height velocity is positively affected by the current estrogen levels, and negatively by growth plate senescence, which reflects prior estrogen exposure. The authors hypothesized that impaired linear growth due to excessive senescence is unmasked by treatment with GnRHa, which removes the stimulatory effect of estrogen on growth. In this study, the height SDS for the CA decreased after the GnRHa treatment, but the height SDS for the BA increased. The height velocity showed a stronger correlation with the BA than with the CA, which supports the hypothesis. A study of 38 Korean girls with CPP who had received GnRHa treatment also reported a significant decrease in the girls' height SDS for their CA and a significant increase in their height SDS for their $\mathrm{BA}^{28)}$. Our findings were consistent with those of these studies. Furthermore, the increases in the height SDSs were greater in the girls whose BAs were more advanced than their CAs.

One of limitations of this study is that majority of the subjects were diagnosed as early puberty, and older than 8 years at the start of treatment. Although there was no evident correlation between CA at initial treatment and difference in height SDS in this study, previous reports have shown that GnRHa treatment is less effective in girls beyond 8 years of age ${ }^{29,30)}$. Younger patients with true precocious puberty may yield different results.

The dose of GnRHa administered during this study is relatively lower than that of previous studies with similar settings in general. Although sex steroids level does not correlate with dose of $\mathrm{GnRHa}$ as long as adequate gonadal suppression is achieved, the dose-effect of GnRHa on IGF-I/IGFBP-3 and growth needs further investigation ${ }^{311}$. Another limitation is that all samples are collected before and during treatment, thus may not fully reflect long-term effects. A follow-up study is required to show longterm effect of GnRHa on IGF-I/IGFBP-3 axis, especially after cessation of treatment.

In summary, gonadal suppression with GnRHa results in a lower height velocity but no change in the serum IGF-I and IGFBP-3 concentrations. The decrease in the height velocity independent of the circulating IGF-I during GnRHa treatment suggests the presence of more direct mechanisms through which sex hormones affect bone growth. Additional studies are required to elucidate other factors that affect the height velocity during and after GnRHa treatment. 


\section{Conflict of interest}

No potential conflict of interest relevant to this article was reported.

\section{References}

1. Grumbach MM, Styne DM. Puberty: ontogeny, neuroendocrinology, physiology, and disorders. In: Wilson JD, Foster DW, Kronenberg HM, Larsen PR, editors. Williams textbook of endocrinology. 9th ed. Philadelphia: W.B. Saunders, 1998:1509-625.

2. Chalumeau M, Chemaitilly W, Trivin C, Adan L, Breart G, Brauner R. Central precocious puberty in girls: an evidence-based diagnosis tree to predict central nervous system abnormalities. Pediatrics 2002;109:61-7.

3. Mogensen SS, Aksglaede L, Mouritsen A, Sorensen K, Main KM, Gideon P, et al. Diagnostic work-up of 449 consecutive girls who were referred to be evaluated for precocious puberty. J Clin Endocrinol Metab 2011;96:1393-401.

4. Kim HK, Kee SJ, Seo JY, Yang EM, Chae HJ, Kim CJ. Gonadotropin-releasing hormone stimulation test for precocious puberty. Korean J Lab Med 2011;31:244-9.

5. Weise M, De-Levi S, Barnes KM, Gafni RI, Abad V, Baron J. Effects of estrogen on growth plate senescence and epiphyseal fusion. Proc Natl Acad Sci U S A 2001;98:68716.

6. Byers S, Moore AJ, Byard RW, Fazzalari NL. Quantitative histomorphometric analysis of the human growth plate from birth to adolescence. Bone 2000;27:495-501.

7. Carel JC, Lahlou N, Roger M, Chaussain JL. Precocious puberty and statural growth. Hum Reprod Update 2004;10:135-47.

8. Crowley WF Jr, Comite F, Vale W, Rivier J, Loriaux DL, Cutler GB Jr. Therapeutic use of pituitary desensitization with a long-acting lhrh agonist: a potential new treatment for idiopathic precocious puberty. J Clin Endocrinol Metab 1981;52:370-2.

9. Attie KM, Ramirez NR, Conte FA, Kaplan SL, Grumbach MM. The pubertal growth spurt in eight patients with true precocious puberty and growth hormone deficiency: evidence for a direct role of sex steroids. J Clin Endocrinol Metab 1990;71:975-83.

10. Cara JF, Burstein S, Cuttler L, Moll GW Jr, Rosenfield RL. Growth hormone deficiency impedes the rise in plasma insulin-like growth factor I levels associated with precocious puberty. J Pediatr 1989;115:64-8.

11. Partsch CJ, Heger S, Sippell WG. Management and outcome of central precocious puberty. Clin Endocrinol (Oxf) 2002;56:129-48.

12. Adan L, Chemaitilly W, Trivin C, Brauner R. Factors predicting adult height in girls with idiopathic central precocious puberty: implications for treatment. Clin Endocrinol (Oxf) 2002;56:297-302.

13. Paul D, Conte FA, Grumbach MM, Kaplan SL. Long-term effect of gonadotropin-releasing hormone agonist therapy on final and near-final height in 26 children with true precocious puberty treated at a median age of less than 5 years. J Clin Endocrinol Metab 1995;80:546-51.

14. Allali S, Lemaire P, Couto-Silva AC, Prete G, Trivin C, Brauner R. Predicting the adult height of girls with central precocious puberty. Med Sci Monit 2011;17:PH41-8.

15. Kauli R, Galatzer A, Kornreich L, Lazar L, Pertzelan A, Laron Z. Final height of girls with central precocious puberty, untreated versus treated with cyproterone acetate or GnRH analogue. A comparative study with re-evaluation of predictions by the Bayley-Pinneau method. Horm Res 1997;47:54-61.

16. Oerter KE, Manasco P, Barnes KM, Jones J, Hill S, Cutler GB Jr. Adult height in precocious puberty after longterm treatment with deslorelin. J Clin Endocrinol Metab 1991;73:1235-40.

17. Greulich WW, Pyle SI. Radiographic atlas of skeletal development of hand wrist. Stanford, CA: Stanford University Press, 1971.

18. Cole TJ. The LMS method for constructing normalized growth standards. Eur J Clin Nutr 1990;44:45-60.

19. Korea Centers for Disease Control and Prevention, Division of Chronic Disease Surveillance, Committee for the Development of Growth Standard for Korean Children and Adolescents; Korean Pediatric Society, Committee for School Health and Public Health Statistics. 2007 Korean children and adolescents growth standard (commentary for the development of 2007 growth chart). Cheongwon: Korea Centers for Disease Control and Prevention, Division of Chronic Disease Surveillance, 2007.

20. Hyun SE, Lee BC, Suh BK, Chung SC, Ko CW, Kim HS, et al. Reference values for serum levels of insulin-like growth factor-I and insulin-like growth factor binding protein-3 in Korean children and adolescents. Clin Biochem 2012;45:16-21.

21. Harris DA, Van Vliet G, Egli CA, Grumbach MM, Kaplan SL, Styne DM, et al. Somatomedin-C in normal puberty and in true precocious puberty before and after treatment with a potent luteinizing hormone-releasing hormone agonist. J Clin Endocrinol Metab 1985;61:152-9.

22. DiMartino-Nardi J, Wu R, Fishman K, Saenger P. The effect of long-acting analog of luteinizing hormone-releasing hormone on growth hormone secretory dynamics in children with precocious puberty. J Clin Endocrinol Metab 1991;73:902-6.

23. Yi KH. Serum IGF-1 and IGFBP-3 levels in central precocious puberty girls treated with gonadotropin releasing hormone agonist (GnRHa). J Korean Soc Pediatr Endocrinol 2011;16:20-3.

24. Kanety H, Karasik A, Pariente C, Kauschansky A. Insulinlike growth factor-I and IGF binding protein- 3 remain high after $\mathrm{GnRH}$ analogue therapy in girls with central precocious puberty. Clin Endocrinol (Oxf) 1996;45:7-12.

25. Sklar CA, Rothenberg S, Blumberg D, Oberfield SE, Levine 
LS, David R. Suppression of the pituitary-gonadal axis in children with central precocious puberty: effects on growth, growth hormone, insulin-like growth factor-I, and prolactin secretion. J Clin Endocrinol Metab 1991;73:7348.

26. Belgorosky A, Rivarola M. Serum IGF-I during treatment of three different types of abnormal puberty, possible role of IGF-I in pubertal maturation [abstract 551]. In: Proceedings of the 76th Annual Meeting of the Endocrine Society; 1994 June 15-18; Anaheim, CA, USA. Bethesda, MD: The Endocrine Society; 1994

27. Weise M, Flor A, Barnes KM, Cutler GB Jr, Baron J. Determinants of growth during gonadotropin-releasing hormone analog therapy for precocious puberty. J Clin Endocrinol Metab 2004;89:103-7.

28. Lee SJ, Yang EM, Seo JY, Kim CJ. Effects of gonadotropin- releasing hormone agonist therapy on body mass index and height in girls with central precocious puberty. Chonnam Med J 2012;48:27-31.

29. Bouvattier C, Coste J, Rodrigue D, Teinturier C, Carel JC, Chaussain JL, et al. Lack of effect of GnRH agonists on final height in girls with advanced puberty: a randomized longterm pilot study. J Clin Endocrinol Metab 1999;84:3575-8.

30. Cassio A, Cacciari E, Balsamo A, Bal M, Tassinari D. Randomised trial of LHRH analogue treatment on final height in girls with onset of puberty aged 7.5-8.5 years. Arch Dis Child 1999;81:329-32.

31. Badaru A, Wilson DM, Bachrach LK, Fechner P, Gandrud LM, Durham E, et al. Sequential comparisons of onemonth and three-month depot leuprolide regimens in central precocious puberty. J Clin Endocrinol Metab 2006;91:1862-7. 